\title{
Changing the rules of the game for future agriculture, the university innovation centre (UIC) model
}

DOI:

10.1109/PICMET.2009.5262238

Link to publication record in Manchester Research Explorer

\section{Citation for published version (APA):}

Grieve, B., Bushell, M., Lant, M., Georghiou, L., \& Malik, K. (2009). Changing the rules of the game for future agriculture, the university innovation centre (UIC) model. In PICMET: Portland International Center for Management of Engineering and Technology, Proceedings/PICMET: Portland Int. Cent. Manage. Eng. Technol., Proc. (pp. 288-298). IEEE. https://doi.org/10.1109/PICMET.2009.5262238

\section{Published in:}

PICMET: Portland International Center for Management of Engineering and Technology, Proceedings|PICMET: Portland Int. Cent. Manage. Eng. Technol., Proc.

\section{Citing this paper}

Please note that where the full-text provided on Manchester Research Explorer is the Author Accepted Manuscript or Proof version this may differ from the final Published version. If citing, it is advised that you check and use the publisher's definitive version.

\section{General rights}

Copyright and moral rights for the publications made accessible in the Research Explorer are retained by the authors and/or other copyright owners and it is a condition of accessing publications that users recognise and abide by the legal requirements associated with these rights.

\section{Takedown policy}

If you believe that this document breaches copyright please refer to the University of Manchester's Takedown Procedures [http://man.ac.uk/04Y6Bo] or contact uml.scholarlycommunications@manchester.ac.uk providing relevant details, so we can investigate your claim.

\section{OPEN ACCESS}




\section{Affordable sensors to support food provision}

Bruce Grieve discusses the role of the Syngenta University Innovation Centre at Manchester University in delivering agri-electronics throughout the food supply chain

\section{Creating innovative products and} techniques for global farming This article describes an ongoing open innovation $(1,2)$ strategy which Syngenta Agribusiness first initiated in 2005. The objective is to enable a step change in farm productivity and crop usage through a fusion of agri-science with non-traditional technologies, such as sensors and informatics. The ultimate aim is to deliver new approaches to food, feed and sustainable fuel supply by:-

Integrating these orthogonal technologies within the existing practices of the company's core businesses, namely Crop Protection products and Seeds, so as to offer innovative $\mathrm{R}$ and $\mathrm{D}$ capabilities.

- Delivering novel products and services by packaging the nontraditional technologies alongside the more routine agri-technologies, so as to better service the ultimate needs of farmers and downstream customers.

\section{The need for a step change in} agriculture

The motivation for this is manifold. First, and possibly foremost, is the projected growth in world population from $6.5 \mathrm{bn}$ in 2006 , to $8 \mathrm{bn}$ by 2025 and $9.3 \mathrm{bn}$ in 2050. Such headline figures are exacerbated by population demographics in the increasingly prosperous developing nations, notably China and India. Another effect of increasing disposable income is the trend towards a high protein, ostensibly, meat diet. To rear poultry for protein, rather than derive it directly from crops, requires around four times the land area in order to deliver the feed volumes. The statistics are even worse for cattle, which require approximately twice as much land area again for the production of feed. In addition to the demands placed on agriculture in feeding a growing populace, the competition for fresh water is having a negative impact on conventional farming practices. Agriculture is the principal user of clean water with around $70 \%$ of all rainfall going into irrigation and other farm duties. Figure 1 provides an illustration of this for the Chishtian region of Pakistan. This provides a clear indication of how current farm water consumption will have to be optimised if food production is to continue in the light of competing demands for drinking water and commerce. A third, and related factor, is climate change which is giving rise to more arid environments in some of the world's most important farming areas. Even those countries which are not forecast to see a reduction in rainfall are not immune, as the unpredictable nature of the weather in intensively-farmed areas means that harvesting cannot be routinely scheduled and may be cancelled altogether if saturated soils prevent farm machinery being deployed. Delayed harvesting often gives rise to crops rotting in the field and so being lost to the food chain. A further secondary effect of climate change is the variability in crop pathogen occurrence and disease spread; a recent example is the UK potato harvest of 2008 where the damp summer resulted in the highest occurrence of potato blight since the Irish Potato Famine of the 1840s.

On top of these global trends is an increasing awareness by national politicians of the importance of securing their own country's domestic food and fuel supplies (3). In the next couple of decades, numerous governments in the oil-based economies intend to derive substantial volumes of their transport needs from second generation energy crops. As a consequence, yields from existing arable land must increase by $50 \%$ if the current $400 \mathrm{M}$ hectares of Amazonian rain forest are to be protected. Historically, Latin America has provided for the shortfall in food for Asia, however, this is unlikely to be sustainable in the future. Given this context, the worldwide implications for farming dictate that radical changes have to occur to avoid devastation. This view is supported by Professor John Beddington, the UK Government Chief Scientist, who recently commented; "The agriculture industry needs to double its food production, using less water than today ... The food crisis will bite more quickly than climate change" (4). The technology opportunities for sensors in food and farming were then expanded upon by Professor Beddington in this very journal (5). It is this background that has driven Syngenta to take a prescient position

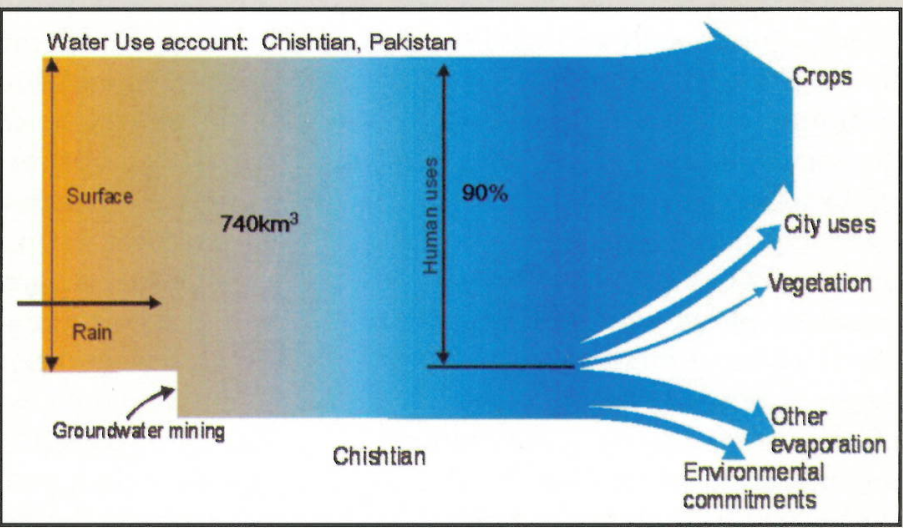

Figure 1. Water usage profile - Chishtian region of Pakistan (Source: Cook and Woolley, 'CGIAR Challenge Program on Water and Food' www.waterandfood.org) 
and seek partnerships with academic groups and companies normally alien to the biotechnology sector. The University Innovation Centre concept is one element of this research strategy.

\section{The changing nature of agribusiness}

During the 1990s, the chemical production sector in Europe and North America saw considerable upheaval as the business models tended to migrate from one of having large multinational conglomerates with highly integrated and interdependent business units to one of large numbers of divested specialised companies aimed at meeting the needs of a specific customer group. The agri-sector was no exception to this and is now dominated by just six global businesses, between them covering over two-thirds of the world's farm production. The formation of Syngenta from a number of parent businesses has parallels across a number of the majors in the sector, as depicted in Fig. 2.

This chart also illustrates the limited remaining freedom in the agrisector for major company mergers without the infringement of anticompetition laws. As a result, further significant growth in these businesses will be dominated by a need to grow organically through the introduction of innovative new products and research techniques rather than mergers and acquisitions.

\section{The wireless sensors revolution}

The ever increasing access to information on the move, from a combination of low-cost electronics, wireless telemetry and novel sensor science, has already changed the way we shop for goods, travel around, communicate with colleagues or spend our leisure time. This revolution is set to continue apace as micro- and nano-engineering are merged with information science and inexpensive printable plastic semiconductors. These changes have been catalysed by a number of circumstances, which are mostly unrelated to the agricultural sector. Examples include the USA's 'Enhanced-911' phone capability, which embeds a new generation of low cost GPS receivers within mobile phone handsets to pinpoint

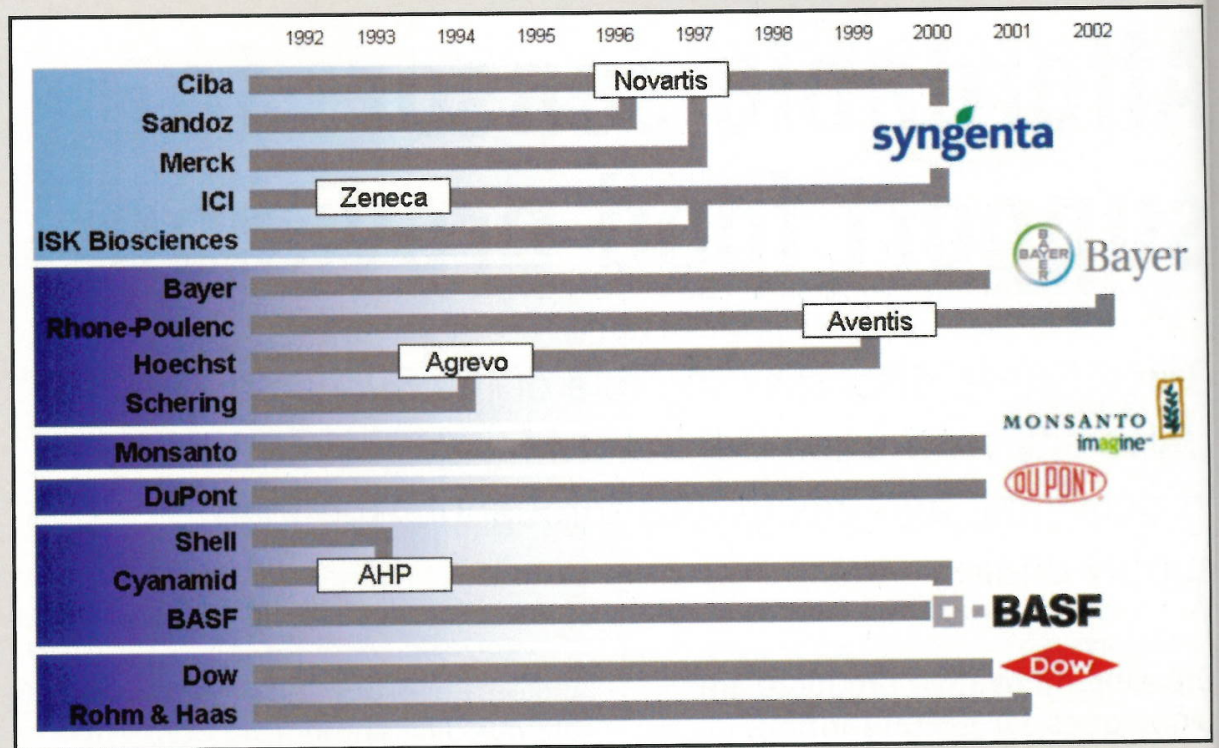

Figure 2. Consolidation in the Agriscience Sector (Source: Phillips McDougall).

the location of a call made to the emergency services. Such systems are rapidly increasing the availability of cost effective wireless-enabled positioning technology that may act as a platform for sensing systems. Again in the USA, the supermarket chain Wall-Mart has dictated to its top 100 suppliers that they must provide Radio Frequency Identification (RFID) tags on all their inventory. Existing tags are too expensive to meet this need without increasing costs to supermarket consumers so the industry is moving towards printable polymer electronics in an attempt to hit the goal of a sub 1 cent tag. Such circuit techniques may then be used to form disposable sensor platforms for 'smart item' tagging and other duties. The growth in portable computing has also given rise to the ubiquitous availability in homes, businesses and cities of RF bandwidth with direct access to internet portals. In addition to the development of the new generations of electronic hardware, there is a matching increase in device intelligence (6). Closer to the agricultural sector, dramatic reductions in gene mapping costs are allowing scientists to examine the methods by which parasites detect their hosts and to emulate these within sensor systems. From this background, agriculture is equally well placed to take advantage of the sensors, electronics and information revolution as other customer-driven sectors. The lack of strategic take up of these agri-electronics technologies by any of the major agri-science businesses can be seen as an opportunity rather than a hindrance.

Charting the landscape for agri-electronics in global farming and food supply

In order for a biotech business to take advantage of sensing and informatics, it is necessary to set into context how such systems may offer benefits to the food and farming sector. Syngenta has adopted a highly structured landscaping approach to scope out the opportunities from a number of enabling technologies, of which sensing is one. These landscape forecast how orthogonal technologies could impact on the agri-sector over a 5-15 year horizon when merged with the products and activities of the company's existing mainstream business units. Details of the landscaping approach cannot be covered within this short article, suffice to say the methodology draws upon business experts and scientists, from within the company and outside, to create a map which is very different from anything that would be produced from teams working in isolation. The Sensors Landscape was compiled in May 2007 and is a reflection of the possibilities offered at that snapshot in time. However, by virtue of the landscaping technique, it is possible to quickly revisit the rationale behind eac step on the map and update it as new business or technology opportunities emerge. 


\section{The University Innovation Centre concept}

The Sensors Landscape gives a picture of what could be achieved; however, this is of little benefit unless there is an appropriate route to develop the required systems. At the one extreme, the launching of an in-house agri-electronics design team is a possibility but this approach has a number of limitations, notably the lead-time and costs of recruiting skilled personnel as well as maintaining a suitably sized group and associated infrastructure. At the other extreme is the intelligent purchaser model, whereby the necessary systems are accuired from third parties such that they meet an agreed specification. This has some superficial appeal for those applications where a clear market demand can be defined for existing electronic systems which are currently almost capable of doing the duty.

These types of potential products are few and far between as such obvious exemplars will typically have been previously exploited. The intelligent purchaser approach is also deficient for introducing truly novel technologies as blindly following market-pull is unlikely to make the necessary linkages between the status quo and the future possibilities. This may be summarised by the phrase; 'how can you buy a technology that does not exist to enable a market that is not currently possible'

The University Innovation Centre (UIC) model ultimately adopted by Syngenta addresses these issues by adapting an open innovation approach similar to that pioneered by RollsRoyce, the aerospace company, and their University Technology Centres (UTCs). The Syngenta concept has parallels to the UTCs in having ring-fenced academics tasked with delivering the medium-term proofof-concept technologies, via direct business funding, and the related longer-term underpinning sciences, via grant proposals in partnership with the Research Councils. Where the critical difference lies is in the scope of the technologies addressed. Unlike the UTCs, which are designed to replace and enhance previous in-house core capabilities, the Syngenta concept is to use the Centres to identify and deliver technologies which are currently not core to the business and may never be core. The rationale is that these UICs will provide the technology platforms that can then yield research methods or complementary systems for integration with the existing mainstream products and practices. The competitive advantage offered by this approach is not dependant upon Syngenta manufacturing the systems arising from the UICs. Instead, the model is that the UICs work alongside the company's business development teams to identify the markets that can be opened up by having access to hitherto unavailable enabling technologies. They then deliver the prototypes for verification in field trials and at that point handover the now proven technologies under a Syngenta/ University license to third party device manufacturing companies. In this way, Syngenta may then globally source appropriately engineered commercial systems and the UICs can move on to their next projects.

The first Syngenta UIC was launched at the University of Manchester in late 2007 and is focused on the delivery of sensors and agrielectronics. The choice of Manchester for this initial UIC was strongly influenced by the merger of the Victoria University of Manchester and UMIST in 2005.

\section{Delivering agri-electronics for future food and crop supply}

Since its inception, the Sensors UIC at Manchester has gradually started to populate the Landscape map with medium-term specific projects addressing such area as:-

n "Farm-to-fork" management of wastage in the perishable goods supply chain by fusing plant genetics and crop input data with package level remote sensing of produce stress.

- In-field 'sentinel' sensors for monitoring the earliest phases of disease ingress allowing crop protection products to be prescribed and targeted with surgical precision.

- Wide area subsoil phenotype imaging for accelerated isolation of genetic traits in the breeding of climate tolerant crops.

- In-process enzyme sensing for efficient processing of second generation fuel crops.

The next phase in this agri-electronic evolution is to integrate affordable in-farm biosensing of fruits and vegetables with the downstream needs of food processors. In this way, greater productivity and reduced energy usage and wastage may be achieved by increased raw material uniformity and enabling more tolerant production. This will need a true partnership between companies across the food supply chain. Notably, the processing of high-value crops such as potatoes and tomatoes are seen as ripe for this approach. Such thinking will require a fusion of agri-business strategy with food science and technology. This will be the next goal for the Sensors UIC and industrial partners.

\section{References}

1. Chesbrough, H., Vanhaverbeke, W. and West, J. (2006). 'Open Innovation: researching a new paradigm'. Oxford University Press, UK.

2. Howells, J., James, A. and Malik, K. (2004). Sourcing external technological knowledge: a decision support framework for firms. Int. J. Technology Management, 27 (2/3), 143-154.

3. Vonbraun, J. (2008). The food crisis isn't over. Nature, 256, 701.

4. Randerson, J. (2008). Food crisis will take hold before climate change, warns chief scientist. The Guardian, UK, (7 March).

5. Beddington, J. (2008). Opinion. $J$. Food Sci. Tech., 22 (3), 12.

6. Appleyard. N. and Biddle, M. (2008). 'Electronics, Photonics and Electrical Systems - Key Technology Area 2008-2011', Technology Strategy Board publication. UK Government Office, Swindon, 20-21.

Dr Bruce Grieve FIET, is Director of the Syngenta Sensors University Innovation Centre, Office C39, School of Electrical है Electronic Engineering, The University of Manchester, PO Box 88, Sackville Street, Manchester M60 1QD, UK.

Tel: +44 (0)1613068941

Email:bruce.grieve@manchester.ac.uk Web: www.eee.manchester.ac.uk/syngenta. 